\title{
Synthesis and Antimicrobial Studies of New Trifluoromethylpyrimidine Analogues
}

\author{
Shaikha Saif Al-Neyadi, Alaa Eldin Salem and Ibrahim Mahmoud Abdou \\ Department of Chemistry, University of United Arab Emirates, Abu Dhabi, Al-Ain 15551, United Arab Emirates
}

\begin{abstract}
This paper describes the synthesis of a new series of trifluoromethylpyrimidine and their potential antimicrobial evaluation. We have prepared 10 novel pyrimidine derivatives in high yields and short reaction time using microwave irradiation. Compounds $4 \mathrm{a}, \mathrm{b}$ and 6a,b showed good antimicrobial activity against Gram-positive bacteria; Clostridium perfringens, Bacillus pumilus and Enterococcus faecalis. These compounds were found to be the most potent antimicrobials compared to ampicillin, tetracycline, and streptomycin that showed no activity against Enterococcus faecalis. Compounds 4a,b and 6a,b exhibited great antimicrobial potency against all tested bacteria strains at a MIC of $3.125-100 \mu \mathrm{g} / \mathrm{mL}$ whereas only $4 \mathrm{a}$ showed the antimicrobial activity against Gram-negative bacteria Klebsiella pneumonia with a MIC value $12.5 \mu \mathrm{g} / \mathrm{mL}$.
\end{abstract}

Key words: Synthesis, microwave, fluoropyrimidine, antimicrobial.

\section{Introduction}

In spite of the remarkable growth in human medicines, infectious diseases caused by bacteria, fungi, viruses and parasites are still representing major threats to public health. Their impact is particularly large in developing countries due to the relative unavailability of medicines, while the excessive use of antimicrobial drugs has led to the emergence of widespread bacterial resistance [1]. In 2003, a number of substituted pyrimidines were synthesized and intensively studied as potent and selective inhibitors of Gram positive bacterial DNA polymerase IIIC [2]. Over the last decades, development of drug resistance as well as the appearance of undesirable side effects of some antibiotics [3] has initiated the search for new antimicrobial agents to overcome some of the disadvantages of the existing drugs [4]. Fluorinated pyrimidine derivatives have attracted more attention especially in biological and medicinal chemistry fields because of the unique features of fluorine compounds and their physiological activity $[5,6]$. The introduction

Corresponding author: Ibrahim Mahmoud Abdou, Ph.D., associate professor, research field: organic chemistry. E-mail i.abdou@uaeu.ac.ae. of fluorine atoms into organic compounds often permits dramatic changes in their chemical and pharmaceutical properties [7]. The presence of pyrimidine nucleus in compounds containing fluorine atoms was found enhancing the biological activities, such as anti-viral [8], anti-malarial [9], adenosine receptor [10], anti-cancer agents [11], as well as compounds targeting delayed-type hypersensivity agents [12].

Hence, there is a never lasting demand for synthesis of novel antimicrobial agents with high potency, efficacy and minimum side effects; this work aims to synthesize novel fluoropyrimidine derivatives with high potency and efficiency against different bacterial strains. Our synthetic approach is based on microwave protocols to enhance the yields in shorter times for the targeted compounds 3-5a,b and 6a-f. The antimicrobial activities of the newly synthesized fluoropyrimidine derivatives $4 \mathrm{a}, \mathrm{b}$ and $6 \mathrm{a}, \mathrm{b}$ will be tested against different bacteria strains such as Gram-positive bacteria, Clostridium perfringens, Bacillus pumilus and Enterococcus faecalis and Gram-negative bacteria, Klebsiella pneumonia. Results out of this work will establish a new structure-activity relationships based 
on substitutions at $\mathrm{C}-2$ and $\mathrm{C}-4$ of the pyrimidine ring.

\section{Materials and Methods}

General: Microwave synthetic protocol was done using CEM Microwave system. Melting points were determined on (Pyrex capillary) Gallenkamp apparatus. Infrared spectra was recorded with a Thermo Nicolet Nexus 470 FT-IR spectrometer in the range $4,000-400 \mathrm{~cm}^{-1}$ on samples in potassium bromide disks. ${ }^{1} \mathrm{H}-\mathrm{NMR}$ spectra, ${ }^{13} \mathrm{C}$-NMR spectra were obtained on Varian Gemini $400 \mathrm{MHz}$ FT NMR spectrometer in $\mathrm{CDCl}_{3}$ and DMSO- $d_{6}$; chemical shifts were recorded in $\delta(\mathrm{ppm})$ units, relative to $\mathrm{Me}_{4} \mathrm{Si}$ as an internal standard. All exchangeable protons were confirmed by addition of $\mathrm{D}_{2} \mathrm{O}$. Thin-layer chromatography (TLC) was carried out on precoated Merck silica gel $\mathrm{F}_{254}$ plates and UV light was used for visualization. Column chromatography was performed on a Merck silica gel. The reagents were purchased from Aldrich and used without further purification. Elemental analysis performed on Leco Model CHN-600 elemental analyzer.

2.1 Microwave Synthesis of 2-Hydroxypyrimidine Analogous (3a,b)

A mixture of 1,3-diketone 1a,b (2.0 mmol), urea $(120 \mathrm{mg}, 2.0 \mathrm{mmol})$ and 2 drops of $\mathrm{HCl}(6.0 \mathrm{M})$ in ethanol $(8 \mathrm{~mL})$ was mixed in $10 \mathrm{~mL}$ CEM-microwave vial. The vial was sealed and irradiated in CEM-microwave reactor at $135^{\circ} \mathrm{C}$ for $5-10 \mathrm{~min}$. The reaction was verified for completion by TLC and recrystallized from a proper solvent to give $3 \mathrm{a}, \mathrm{b}$ in yields $89 \%$ and $84 \%$ respectively.

4-(Thien-2'-yl)-6-(trifluoromethyl)pyrimidin-2-ol (3a): yellow crystals; yield $89 \%$; mp $230{ }^{\circ} \mathrm{C}$; IR ( $\mathrm{KBr}$, $\mathrm{cm}^{-1}$ ): 3,459 (br, OH), 3,088 (C-H aromatic), 1,680 $(\mathrm{CONH}) ;{ }^{1} \mathrm{H}-\mathrm{NMR}$ [DMSO- $\left.d_{6}, 400 \mathrm{MHz}\right]:(\delta, \mathrm{ppm})$ 7.29 (s, 1H, H-5 pyrimidine), 7.30 (t, 1H, thien-2'-yl H-4', J = 4.0 Hz), 7.93 (d, 1H, thien-2'-yl H-5', J = 5.0 $\mathrm{Hz}$ ), 8.29 (d, 1H, thien-2'-yl H-3', J = 4.0 Hz), 12.88 $\left(1 \mathrm{H}, \quad \mathrm{s}, \mathrm{OH}\right.$ exchangeable with $\left.\mathrm{D}_{2} \mathrm{O}\right) ;{ }^{13} \mathrm{C}-\mathrm{NMR}$
[DMSO- $\left.d_{6}, 100 \mathrm{MHz}\right]:(\delta, \mathrm{ppm}) 103.6(\mathrm{C}-5), 120.6$ $\left(\mathrm{CF}_{3}, \mathrm{q}, \mathrm{J}=274 \mathrm{~Hz}\right), 129.1,131.1,132.8\left(\mathrm{C}-3^{\prime}, \mathrm{C}-4^{\prime}\right.$, C-5' thien-2'-yl), 140.5 (C-2' thien-2'-yl), 160.7 (C-6 pyrimidine), 163.5 (C-4 pyrimidine), 165.1 (C-2 pyrimidine). Anal. Calcd for $\mathrm{C}_{9} \mathrm{H}_{5} \mathrm{~F}_{3} \mathrm{~N}_{2} \mathrm{OS}: \mathrm{C}, 43.90 ; \mathrm{H}$, 2.05; N, 11.38; S, 13.02. Found: C, 44.35; H, 2.12; N, 11.66; S, 13.30 .

4-Phenyl-6-(trifluoromethyl)pyrimidin-2-ol (3b): white powder; yield $84 \%$; $\mathrm{mp} 234{ }^{\circ} \mathrm{C}$, from hexane; IR $\left(\mathrm{KBr}, \mathrm{cm}^{-1}\right): 3,489$ (br, OH), 3,076 (CH-aromatic), 1,676 (CONH); ${ }^{1} \mathrm{H}-\mathrm{NMR}$ [DMSO- $d_{6}, 400 \mathrm{MHz}$ : $(\delta$, ppm) 7.22 (s, 1H, H-5 pyrimidine), 7.52-7.61 (m, 3H, aromatic), 8.16-8.17 (m, 2H, aromatic), $12.88(\mathrm{~s}, 1 \mathrm{H}$, $\mathrm{OH}$; exchangeable with $\left.\mathrm{D}_{2} \mathrm{O}\right) ;{ }^{13} \mathrm{C}-\mathrm{NMR}$ [DMSO- $d_{6}$, $100 \mathrm{MHz}]:(\delta$, ppm $) 109.4(\mathrm{C}-5), 122.8\left(\mathrm{CF}_{3}, \mathrm{q}, \mathrm{J}=274\right.$ Hz), 129.0, 130.4, 133.4, 139.8 (phenyl carbons), 161.7 (C-6 pyrimidine), 165.3 (C-4 pyrimidine), 167.8 (C-2 pyrimidine). Anal. Calcd. for $\mathrm{C}_{11} \mathrm{H}_{7} \mathrm{~F}_{3} \mathrm{~N}_{2} \mathrm{O}: \mathrm{C}, 55.01 ; \mathrm{H}$, 2.94; N, 11.66; Found: C, 55.46; H, 3.01; N, 11.94.

\subsection{Microwave Synthesis of 2-Pyrimidine Benzoyl Esters $(5 a, b)$}

To a solution of $3 \mathrm{a}, \mathrm{b}(2 \mathrm{mmol})$ in $15 \mathrm{~mL}$ pyridine, p-fluorobenzoyl chloride (5 mmol, $0.59 \mathrm{~mL}$ ) was added gradually with stirring in ice bath. After the addition is completed, the reaction mixture was heated under microwave irradiation at $100^{\circ} \mathrm{C}$ for about $10 \mathrm{~min}$. The progress of the reaction was monitored by TLC, The solid obtained was washed with water and crystallized from ethanol to give the desired compounds $4 a, b$.

4-(Thien-2'-yl)-6-(trifluoromethyl)-2-pyrimidinyl-4 "-fluorobenzoate (4a): white crystals, yield 85\%; mp 105-7 ${ }^{\circ} \mathrm{C}$; IR $\left(\mathrm{KBr}, \mathrm{cm}^{-1}\right): 3,116(\mathrm{C}-\mathrm{H}$, aromatic), 1,757 $(\mathrm{C}=\mathrm{O}), 1,603(\mathrm{C}=\mathrm{C}), 1,429(\mathrm{C}=\mathrm{N}) ;{ }^{1} \mathrm{H}-\mathrm{NMR}\left[\mathrm{CDCl}_{3}\right.$, $400 \mathrm{MHz}]:(\delta$, ppm $)$ 7.17-7.22 (m, 3H, phenyl \& thien-2'-yl H-4'), 7.64 (dd, 1H, thien-2'-yl H-5', J = 4.9 $\mathrm{Hz}$ ), 7.79 (s, 1H, H-5 pyrimidine), 7.92 (dd, 1H, thien-2'-yl H-3', J = $3.7 \mathrm{~Hz}), 8.24(\mathrm{~m}, 2 \mathrm{H}$, aromatic);

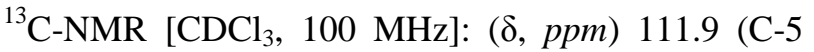
pyrimidine), 115.41 (phenyl carbon), $122.8\left(\mathrm{CF}_{3}, \mathrm{q}, \mathrm{J}=\right.$ 
$274 \mathrm{~Hz}), \quad 127.2, \quad 127.3, \quad 127.4, \quad 128.9, \quad 129.0$ (Ar-carbons), 148.3 (C-2' thien-2'-yl), 161.5 (C-6 pyrimidine), 163.2 (C-4 pyrimidine), $165.4(\mathrm{C}=\mathrm{O})$, 165.5 (C-F, aromatic), 165.7 (C-2 pyrimidine). Anal. Calcd for $\mathrm{C}_{16} \mathrm{H}_{8} \mathrm{~F}_{4} \mathrm{~N}_{2} \mathrm{O}_{2} \mathrm{~S}: \mathrm{C}, 52.18 ; \mathrm{H}, 2.19 ; \mathrm{N}, 7.61 ; \mathrm{S}$, 8.71; Found: C, 52.63; H, 2.26; N, 7.89; S, 8.99.

4-Phenyl-6-(trifluoromethyl)pyrimidin-2-yl

4'-fluorobenzoate (4b): white powder; yield 83\%; mp $114{ }^{\circ} \mathrm{C}$; IR ( $\left.\mathrm{KBr}, \mathrm{cm}^{-1}\right): 3,118(\mathrm{C}-\mathrm{H}$, aromatic), 1,758 $(\mathrm{C}=\mathrm{O}), \quad 1,602 \quad(\mathrm{C}=\mathrm{C}), \quad 1,428 \quad(\mathrm{C}=\mathrm{N}) ; \quad{ }^{1} \mathrm{H}-\mathrm{NMR}$ $\left[\mathrm{DMSO}-d_{6}, 400 \mathrm{MHz}\right]:(\delta$, ppm $) 7.26(1 \mathrm{H}, \mathrm{s}, \mathrm{H}-5$ pyrimidine), 7.53-7.61 (m, 5H, aromatic), 7.93-7.95 (m, $2 \mathrm{H}$, aromatic), 8.25-8.27 (m, $2 \mathrm{H}$, aromatic); ${ }^{13} \mathrm{C}-\mathrm{NMR}$

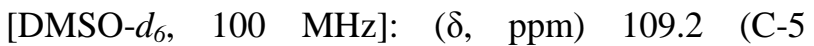
pyrimidine), 115.1 (aromatic carbons), 122.8 ( $\mathrm{CF}_{3}, \mathrm{q}, \mathrm{J}$ = $274 \mathrm{~Hz}), 127.2,127.3,128.9,129.0,129.8,133.4$ (aromatic carbons), 148.8 (C-6 pyrimidine), 161.5 (C-4 pyrimidine), $163.2(\mathrm{C}=\mathrm{O}), 165.3$ (C-F, aromatic), 165.8 (C-2 pyrimidine). Anal. Calcd for $\mathrm{C}_{18} \mathrm{H}_{10} \mathrm{~F}_{4} \mathrm{~N}_{2} \mathrm{O}_{2}$ : C, 59.68; H, 2.78; N, 7.73; Found: C, 60.13; H, 2.85; N, 8.01 .

\subsection{Microwave Synthesis of 2-Chloropyrimidine Derivatives $(5 a, b)$}

In $10 \mathrm{~mL}$ CEM-microwave vessel, two drops of pyridine were added to a mixture of $3 \mathrm{a}, \mathrm{b}(2.0 \mathrm{mmol})$ and $\mathrm{POCl}_{3}(4.0 \mathrm{mmol}, 0.37 \mathrm{ml})$. The vial was sealed and the mixture was heated under microwave irradiation at $100^{\circ} \mathrm{C}$ for $25 \mathrm{~min}$. The reaction mixture was cooled to room temperature then poured into an ice-cold water $(10 \mathrm{~mL})$ under vigorous stirring. The $\mathrm{pH}$ was adjusted to $\mathrm{pH}-8$ and the resulting mixture was stirred for 15 minutes. The obtained light brown solid was filtered, washed with water $(2 \times 10 \mathrm{~mL})$ and dried under reduced pressure for 2 hours.

2-Chloro-4-(thien-2'-yl)-6-(trifluoromethyl)pyrimid ine (5a): brown crystals; yield 96\%; mp $109{ }^{\circ} \mathrm{C}$; ${ }^{1} \mathrm{H}-\mathrm{NMR}$ [DMSO- $d_{6}, 400 \mathrm{MHz}$ ]: $(\delta, \mathrm{ppm}) 7.30-7.33(\mathrm{t}$, $1 \mathrm{H}$, thien-2'-yl H-4', $\mathrm{J}=4.0 \mathrm{~Hz}), 7.84(1 \mathrm{H}, \mathrm{s}, \mathrm{H}-5$ pyrimidine), $7.92(\mathrm{~d}, 1 \mathrm{H}$, thien-2'-yl H-5' $\mathrm{J}=5.0 \mathrm{~Hz}$ ), $8.21(\mathrm{~d}, 1 \mathrm{H}$, thien-2'-yl H-3', $\mathrm{J}=4.0 \mathrm{~Hz}) ;{ }^{13} \mathrm{C}-\mathrm{NMR}$

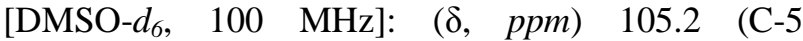
pyrimidine), $122.0\left(\mathrm{CF}_{3}, \mathrm{q}, \mathrm{J}=274 \mathrm{~Hz}\right), 129.7,131.5$, 133.3 (C-3', C-4', C-5' thien-2'-yl), 140.1 (C-2' thien-2'-yl), 163.6 (C-6 pyrimidine), 164.7 (C-4 pyrimidine), 165.1 (C-2 pyrimidine).

2-Chloro-4-phenyl-6-(trifluoromethyl)pyrimidine (5b): brown crystals; yield $95 \%$; $\mathrm{mp} 105^{\circ} \mathrm{C}$, from ethanol; ${ }^{1} \mathrm{H}-\mathrm{NMR}$ [DMSO- $\left.d_{6}, 400 \mathrm{MHz}\right]:(\delta, p p m)$ 7.58-7.67 (m, 3H, aromatic), $7.75(\mathrm{~s}, 1 \mathrm{H}, \mathrm{H}-5$ pyrimidine), 8.16-8.17 (m, 2H, aromatic); ${ }^{13} \mathrm{C}-\mathrm{NMR}$

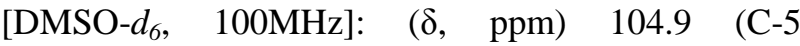
pyrimidine), $122.5\left(\mathrm{CF}_{3}, \mathrm{q}, \mathrm{J}=274 \mathrm{~Hz}\right), 129.7,131.4$, 132.9, 136.4 (aromatic carbons), 157.5 (C-6 pyrimidine), 162.7 (C-2 pyrimidine), 165.1 (C-4 pyrimidine).

\subsection{Microwave Amination Procedure (6a-f)}

To a solution of 4-aryl-2-chloro-6-(trifluoro methyl)pyrimidine $5 \mathrm{a}, \mathrm{b}$ in toluene $(15 \mathrm{~mL})$, an excess of amine was added at room temperature in $35 \mathrm{~mL}$ CEM microwave vial. The vial was sealed and the reaction mixture was heated under microwave irradiation at $80-100^{\circ} \mathrm{C}$ for $5-10 \mathrm{~min}$. The progress of the reaction was monitored by TLC and after completion; the reaction mixture was quenched with water $(0.5 \mathrm{~mL})$ and a solution of sodium carbonate $(0.1$ $\mathrm{g}, 2 \mathrm{mmol}$ ) was added with stirring at room temperature. The reaction mixture was extracted in ether and the organic layer was dried over anhydrous $\mathrm{MgSO}_{4}$. The product purified by silica gel column chromatography with ethylacetate: hexane (6:4) to give pure products 6a-f.

2-( $N$-Cyclopentyamino)-4-(thien-2'-yl)-6-(trifluoro methyl)pyrimidine (6a): pale yellow crystal, yield $86 \%$; mp $99{ }^{\circ} \mathrm{C}$; IR $\left(\mathrm{KBr}, \mathrm{cm}^{-1}\right): 3,544(-\mathrm{NH}), 3,089(\mathrm{C}-\mathrm{H}$, aromatic), 2,931 (aliphatic $\mathrm{C}-\mathrm{H}), \quad 1,478 \quad(\mathrm{C}=\mathrm{N})$; ${ }^{1} \mathrm{H}-\mathrm{NMR}\left[\mathrm{CDCl}_{3}, 400 \mathrm{MHz}\right]:(\delta, \mathrm{ppm})$ 1.47-1.73 (m, 8 $\mathrm{H}$, cyclopentyl), 4.30-4.36 (m, 1H, cyclopentyl), 5.35 $\left(\mathrm{d}, 1 \mathrm{H},-\mathrm{NH}\right.$, exchanges with $\left.\mathrm{D}_{2} \mathrm{O}, \mathrm{J}=6 \mathrm{~Hz}\right), 7.08(1 \mathrm{H}$, s, $\mathrm{H}-5$ pyrimidine), 7.12-7.15 (m, $1 \mathrm{H}$, thien-2'-yl H-4'), 7.49-7.51 (m, 1H, thien-2'-yl H-5'), $7.70(\mathrm{~m}, 1 \mathrm{H}$, 
thien-2'-yl H-3'); ${ }^{13} \mathrm{C}-\mathrm{NMR}\left[\mathrm{CDCl}_{3}, 100 \mathrm{MHz}\right]:(\delta$, ppm) 23.7 (C-3, C-4 cyclopentyl), 33.1 (C-2, C-5 cyclopentyl), 53.2 (C-1 cyclopentyl), 99.6 (C-5 pyrimidine), $120.7\left(\mathrm{CF}_{3}, \mathrm{q}, \mathrm{J}=274 \mathrm{~Hz}\right), 128.3,130.4$, 132.4 (C-3', C-4', C-5' thien-2'-yl), 142.6 (C-2' thien-2'-yl), 156.5 (C-6 pyrimidine), 161.8 (C-4 pyrimidine), 162.8 (C-2 pyrimidine). Anal. Calcd. for $\mathrm{C}_{14} \mathrm{H}_{14} \mathrm{~F}_{3} \mathrm{~N}_{3} \mathrm{~S}$ : C, 53.66; H, 4.50; N, 13.41; S, 10.23; Found: C, 54.11; H, 4.57; N, 13.69; S, 10.51 .

2-(N-Cycloheptylamino)-4-(thien-2'-yl)-6-(trifluoro methyl)pyrimidine (6b): white powder, $\mathrm{R}_{\mathrm{f}}=0.66$ (ethylacetate:hexane 1:1), yield $77 \%$; mp $111-13{ }^{\circ} \mathrm{C}$; IR $\left(\mathrm{KBr}, \mathrm{cm}^{-1}\right):$ 3,531 (-NH), 3,054 (C-H, aromatic), 2,884 (aliphatic $\mathrm{C}-\mathrm{H}), 1,600(\mathrm{C}=\mathrm{C}), 1,463(\mathrm{C}=\mathrm{N})$; ${ }^{1} \mathrm{H}-\mathrm{NMR}\left[\mathrm{CDCl}_{3}, 400 \mathrm{MHz}\right.$ ]: ( $\delta$, ppm) 1.55-1.64 (m, $10 \mathrm{H}$, cycloheptyl), 2.05-2.06 (m, 2H, cycloheptyl), $4.09(\mathrm{~m}, 1 \mathrm{H}$, cycloheptyl $), 5.36(\mathrm{~d}, 1 \mathrm{H},-\mathrm{NH}$, exchanges with $\left.\mathrm{D}_{2} \mathrm{O}, \mathrm{J}=4.0 \mathrm{~Hz}\right), 7.07(1 \mathrm{H}, \mathrm{s}, \mathrm{H}-5$ pyrimidine), 7.13 (t, $1 \mathrm{H}$, thien-2'-yl H-4', J = 4.0 Hz), 7.50-7.51 (d, $1 \mathrm{H}$, thien-2'-yl H-5' $\mathrm{J}=4.0 \mathrm{~Hz}$ ), 7.73 (m, $1 \mathrm{H}$, thien-2'-yl H-3'); ${ }^{13} \mathrm{C}-\mathrm{NMR}\left[\mathrm{CDCl}_{3}, 100 \mathrm{MHz}\right]:(\delta$, ppm) 24.2 (C-3, C-6 cycloheptyl), 30.9 (C-4, C-5 cycloheptyl), 34.6 (C-2, C-7 cyclopentyl), 53.2 (C-1 cycloheptyl), 101.0 (C-5 pyrimidine), $120.8\left(\mathrm{CF}_{3}, \mathrm{q}, \mathrm{J}=\right.$ $274 \mathrm{~Hz}), 127.1,128.8,131.2$ (C-3', C-4', C-5' thien-2'-yl), 141.9 (C-2' thien-2'-yl), 156.9 (C-6 pyrimidine), 161.7 (C-4 pyrimidine), 167.2 (C-2 pyrimidine). Anal. Calcd for $\mathrm{C}_{16} \mathrm{H}_{18} \mathrm{~F}_{3} \mathrm{~N}_{3} \mathrm{~S}: \mathrm{C}, 56.29 ; \mathrm{H}$, 5.31; N, 12.31; S, 9.39; Found: C, 56.74; H, 5.38; N, $12.59 ; \mathrm{S}, 9.67$.

2-(N-Methylpiperazin-1'-yl)-4-(thien-2'-yl)-6-(triflu oromethyl)pyrimidine (6c): white powder, $R_{f}=0.16$ (ethylacetate:hexane 1:1), yield $89 \%$; mp $109-11{ }^{\circ} \mathrm{C}$; IR $\left(\mathrm{KBr}, \mathrm{cm}^{-1}\right):$ 3,095 (C-H, aromatic), 2,911 (aliphatic $\mathrm{C}-\mathrm{H}), \quad 1,593 \quad(\mathrm{C}=\mathrm{C}), 1,452 \quad(\mathrm{C}=\mathrm{N}), \quad 1,254 \quad(\mathrm{C}-\mathrm{N})$; ${ }^{1} \mathrm{H}-\mathrm{NMR}\left[\mathrm{CDCl}_{3}, 400 \mathrm{MHz}\right]:(\delta$, ppm $) 2.35$ (s, 3H, methyl group), 2.49-2.50 (m, $4 \mathrm{H}$, piprazine ring), 3.93-3.95 (m, 4H, piprazine ring ), $7.05(1 \mathrm{H}, \mathrm{s}, \mathrm{H}-5$ pyrimidine), 7.14 (t, $1 \mathrm{H}$, thien-2'-yl H-4', $\mathrm{J}=4.0 \mathrm{~Hz}$ ), $7.50(\mathrm{dd}, 1 \mathrm{H}$, thien-2'-yl H-5', J = 4.9 Hz ), 7.72 (dd, $1 \mathrm{H}$, thien-2'-yl H-3', $\mathrm{J}=3.7 \mathrm{~Hz}) ;{ }^{13} \mathrm{C}-\mathrm{NMR}\left[\mathrm{CDCl}_{3}\right.$,
$100 \mathrm{MHz}]:$ ( $\delta, \mathrm{ppm}) 43.6\left(\mathrm{CH}_{3}\right), 46.2$ (piprazine), 54.9 (piprazine), 99.1 (C-5), $120.8\left(\mathrm{CF}_{3}, \mathrm{q}, \mathrm{J}=274 \mathrm{~Hz}\right)$, $127.8,128.3,130.2$ (C-3', C-4', C-5' thien-2'-yl), 142.7 (C-2' thien-2'-yl), 156.6 (C-6 pyrimidine), 161.4 (C-4 pyrimidine), 161.5 (C-2 pyrimidine). Anal. Calcd. for $\mathrm{C}_{14} \mathrm{H}_{15} \mathrm{~F}_{3} \mathrm{~N}_{4} \mathrm{~S}$ : C, 51.21; H, 4.60; N, 17.06; S, 9.77; Found: C, 51.66; H, 4.67; N, 17.34; S, 10.02 .

2-(N-Cyclopentylamino)-4-phenyl-6-(trifluorometh yl)pyrimidine (6d): pale yellow crystal, $R_{f}=0.66$ (ethylacetate: hexane 1:1), yield $78 \%$; mp $103{ }^{\circ} \mathrm{C}$; IR $\left(\mathrm{KBr}, \mathrm{cm}^{-1}\right)$ : 3,542 (-NH), 3,056 (C-H, aromatic), 2,918 (aliphatic C-H), 1,597 $(\mathrm{C}=\mathrm{C}), 1,456(\mathrm{C}=\mathrm{N}) ;{ }^{1} \mathrm{H}-\mathrm{NMR}$ $\left[\mathrm{CDCl}_{3}, 400 \mathrm{MHz}\right]:(\delta, \mathrm{ppm}) 1.51-1.53(\mathrm{~m}, 2 \mathrm{H}$, cyclopentyl), 1.64-1.75 (m, 4H, cyclopentyl), 2.08-2.11 (m, 2H, cyclopentyl), 4.40 (br, 1H, cyclopentyl), $5.41\left(\mathrm{~d},-\mathrm{NH}\right.$, exchanges with $\mathrm{D}_{2} \mathrm{O}, \mathrm{J}=$ $6.8 \mathrm{~Hz}), 7.22(1 \mathrm{H}, \mathrm{s}, \mathrm{H}-5$ pyrimidine), 7.48-7.49 (m, $3 \mathrm{H}$, aromatic), $8.05\left(\mathrm{~m}, 2 \mathrm{H}\right.$, aromatic); ${ }^{13} \mathrm{C}-\mathrm{NMR}$ $\left[\mathrm{CDCl}_{3}, 100 \mathrm{MHz}\right]:(\delta, \mathrm{ppm}) 23.7$ (C-3, C-4 cyclopentyl), 33.1 (C-2, C-5 cyclopentyl), 53.2 (C-1 cyclopentyl), 99.6 (C-5 pyrimidine), $120.4\left(\mathrm{CF}_{3}, \mathrm{q}, \mathrm{J}=\right.$ $274 \mathrm{~Hz}$ ), 128.3, 130.4, 132.4, 142.6 (aromatic carbons), 156.5 (C-6 pyrimidine), 161.8 (C-4 pyrimidine), 162.0 (C-2 pyrimidine). Anal. Calcd. for $\mathrm{C}_{16} \mathrm{H}_{16} \mathrm{~F}_{3} \mathrm{~N}_{3}$ : C, 62.53; H, 5.25; N, 13.67; Found: C, 62.98; H, 5.32; N, 13.95 .

2-(N-Cycloheptylamino)-4-phenyl-6-(trifluorometh yl)pyrimidine (6e): white powder, $R_{f}=0.68$ (ethylacetate:hexane 1:1), yield 83\%; mp $115-18{ }^{\circ} \mathrm{C}$; IR $\left(\mathrm{KBr}, \mathrm{cm}^{-1}\right): 3,548(-\mathrm{NH}), 3,088(\mathrm{C}-\mathrm{H}$, aromatic), 2,923 (aliphatic $\mathrm{C}-\mathrm{H}), 1,585(\mathrm{C}=\mathrm{C}), 1,461(\mathrm{C}=\mathrm{N})$; ${ }^{1} \mathrm{H}-\mathrm{NMR}\left[\mathrm{CDCl}_{3}, 400 \mathrm{MHz}\right]$ : $(\delta, \mathrm{ppm}) 1.56-1.73$ (m, $10 \mathrm{H}$, cycloheptyl), 2.06 (m, 2H, cycloheptyl ), 4.17 (br,1H, cycloheptyl), $5.42(\mathrm{~d}, 1 \mathrm{H}, \mathrm{NH}$, exchanges with $\left.\mathrm{D}_{2} \mathrm{O}, \mathrm{J}=8.0 \mathrm{~Hz}\right), 7.21(1 \mathrm{H}, \mathrm{s}, \mathrm{H}-5$ pyrimidine $)$, 7.48-7.50 (m, 3H, aromatic), $8.05(\mathrm{~m}, 2 \mathrm{H}$, aromatic); ${ }^{13} \mathrm{C}-\mathrm{NMR}$ [CDCl 3 , $100 \mathrm{MHz}$ : ( $\delta$, ppm) 24.1 (C-3, C-6 cyclopentyl), 28.3 (C-4, C-5 cycloheptyl), 34.7 (C-2, C-7 cycloheptyl), 52.1 (C-1 cycloheptyl), 101.0 (C-5 pyrimidine ), $120.8\left(\mathrm{CF}_{3}, \mathrm{q}, \mathrm{J}=274 \mathrm{~Hz}\right), 127.1,128.8$, 131.2, 136.6 (aromatic carbons), 156.2 (C-6 
pyrimidine), 161.8 (C-4 pyrimidine), 167.2 (C-2 pyrimidine). Anal. Calcd. for $\mathrm{C}_{18} \mathrm{H}_{20} \mathrm{~F}_{3} \mathrm{~N}_{3}: \mathrm{C}, 64.46 ; \mathrm{H}$, 6.01 ; N, 12.53; Found: C, 64.91; H, 6.08; N, 12.81.

2-(N-Methylpiperazin-1'-yl)-4-phenyl-6-(trifluorom ethyl)pyrimidine (6f): white powder, $R_{f}=0.15$ (ethylacetate:hexane 1:1), yield $82 \%$; mp $114-16{ }^{\circ} \mathrm{C}$; IR $\left(\mathrm{KBr}, \mathrm{cm}^{-1}\right): 3,083(\mathrm{C}-\mathrm{H}$, aromatic), 2,924 (aliphatic $\mathrm{C}-\mathrm{H}), 1,583(\mathrm{C}=\mathrm{C}), 1,457(\mathrm{C}=\mathrm{N})$; ${ }^{1} \mathrm{H}-\mathrm{NMR}\left[\mathrm{CDCl}_{3}\right.$, 400MHz]: ( $\delta, \mathrm{ppm}) 2.35$ (s, 3H, methyl), 2.49-2.50 (m, $4 \mathrm{H}$, piprazine ring), $3.98(\mathrm{~m}, 4 \mathrm{H}$, piprazine ring), 7.19 (1H, s, H-5 pyrimidine), 7.46-7.48 (m, 3H, aromatic), 8.03-8.05 (m, 2H, aromatic); ${ }^{13} \mathrm{C}-\mathrm{NMR}\left[\mathrm{CDCl}_{3}, 100\right.$ $\mathrm{MHz}]: \quad(\delta, \quad p p m) 43.7 \quad\left(\mathrm{CH}_{3}\right), 46.2 \quad(\mathrm{C}-2, \quad \mathrm{C}-6$ methylpiprazine), 54.9 (C-3, C-5 methylpiprazine), 100.6 (C-5 pyrimidine), $120.9\left(\mathrm{CF}_{3}, \mathrm{q}, \mathrm{J}=274 \mathrm{~Hz}\right)$, 127.2, 128.8, 131.2, 136.7 (aromatic carbons), 156.4 (C-6 pyrimidine), 161.7 (C-4 pyrimidine ), 166.8 (C-2 pyrimidine). Anal. Calcd. for $\mathrm{C}_{16} \mathrm{H}_{17} \mathrm{~F}_{3} \mathrm{~N}_{4}: \mathrm{C}, 59.62 ; \mathrm{H}$, 5.32; N, 17.38; Found: C, 60.07; H, 5.39; N, 17.66.

\subsection{Determination of MIC (Minimum Inhibitory Concentration)}

\subsubsection{Microdilution Method}

The 96-well microtitre assay using resazurin as the indicator of cell growth [13] was employed for the determination of the minimum inhibitory concentration. Resazurin is an oxidation-reduction indicator used for the evaluation of microbial growth. The blue non-fluorescent dye turned into pink color with fluorescent when reduced to resorufin by oxidoreductase within cells. A $50 \mu \mathrm{L}$ sterile deionized water was added to each well. A $50 \mu \mathrm{L}$ purified test compound was added in the first well of horizontal row and double diluted horizontally in each well. Last well was added with $100 \mu \mathrm{L}$ of sterile deionized water without test compound, used as control. A $100 \mu \mathrm{L}$ double strength nutrient broth was added in each well then $10 \mu \mathrm{L}$ test organisms (OD at $600 \mathrm{~nm} \sim 1$ ) added to each well. This was followed by the addition of $1 \mu \mathrm{L}$ resazurin ( $1 \%$ stock prepared). The microtitre plate was incubated at $37{ }^{\circ} \mathrm{C}$ for $18-24 \mathrm{~h}$. The well with blue color (no viable bacteria) just before the pink well (viable bacteria) was taken as MIC value. The inoculated plates incubated. MIC was defined as the lowest concentration of the tested plant extracts that prevented resazurin color change from blue to pink.

\subsubsection{Determination of Zones of the Inhibition}

All the synthesized compounds were tested for their in vitro growth inhibitory activity against a panel of standard strains of pathogenic microorganism including Gram-positive and Gram-negative bacteria. Gram-positive bacteria are Clostridium perfringens, Bacillus pumilus and Enterococcus faecalis and Gram-negative bacteria's are Klebsiella pneumonia and Pseudomonas aeruginosa. The efficacy was determined by zone of inhibition values using disk diffusion technique [14]. To each petri-plate, $20 \mathrm{~mL}$ of sterilized medium was added. After the agar had set, $10 \%$ of inoculum of each microorganism culture was added to each petri-plate and spread thoroughly. Sterilized Whatmann no. 1 filter papers discs (diameter $6 \mathrm{~mm}$ ) were thoroughly moistened with the synthesized compounds of specific concentrations 100 $\mu \mathrm{g} / \mathrm{mL}$ in DMSO and placed on seeded agar plates. Paper discs moistened with DMSO were considered as negative control. Discs saturated with Ampicillin, Tetracycline and Streptomycin at the same concentrations were taken as standard (positive control). The plates were incubated at $37^{\circ} \mathrm{C}$ for $24 \mathrm{~h}$. The clear zone of inhibition around disc-paper demonstrated the relative susceptibility towards the synthesized derivatives.

\section{Results and Discussion}

Fluorine has played a pivotal role in novel drug discovery for modulating physical and biological properties of molecules [15-18]. Incorporation of one or several fluorine atoms into an organic molecule may enhance its biological activity, bioavailability, metabolic stability and lipophilicity due to intrinsic properties of fluorine atoms such as high electronegativity and small atomic radius [19]. 


\subsection{Chemical Synthesis}

All of the synthetic steps described in this paper were carried out under controlled microwave irradiation. The conversion of diketone to the targeted substituted pyrimidine 3-6 involving cyclization, chlorination and amination carried out under microwave irradiation yielded 3a,b (84-89\%), 5a,b (95-96\%) and 6a-f (77-89\%) respectively (Table 1). Synthetic methodologies began by the reaction between trifluorobutane-1,3-dione $1 \mathrm{a}, \mathrm{b}$ and urea via nucleophilic substitution at the vinyl carbon atom, followed by cyclization to form 6-trifluoromethyl pyrimidin-2-ol 3a,b. The structure and properties of the final products obtained have been established by their melting point, elemental analysis, IR, ${ }^{1} \mathrm{H}-\mathrm{NMR}$ and ${ }^{13} \mathrm{C}-\mathrm{NMR}$ spectroscopy. The structure of 2-hydroxy-4-(thien-2'-yl)-6-trifluoromethyl

pyrimidine 3a was confirmed using IR-spectroscopy which revealed by the appearance of broad band at $v=$ $3,459 \mathrm{~cm}^{-1}$ corresponding to a tautomeric hydroxyl group $(\mathrm{N}=\mathrm{C}-\mathrm{OH})$. While, a sharp band appeared at $\mathrm{v}=$ $1,680 \mathrm{~cm}^{-1}$ assigned for the keto-group (CONH) in $3 \mathrm{a}$. The ${ }^{1} \mathrm{H}-\mathrm{NMR}$ (400 MHz, DMSO- $d_{6}$ ) spectrum of compound 3a showed a sharp signal at $\delta=7.29 \mathrm{ppm}$ assigned to the $\mathrm{H}-5$ of pyrimidine. The thiophene protons showed the following splitting pattern: the $\mathrm{H}-4^{\prime}$ appeared as triplet at $\delta=7.30 \mathrm{ppm}$ with coupling constant $\mathrm{J}=4.0 \mathrm{~Hz}$, the $\mathrm{H}-5^{\prime}$ resonated as a doublet of doublet at $\delta=7.93$ ppm with coupling constant $\mathrm{J}_{\mathrm{H} 5{ }^{\prime}, \mathrm{H}^{\prime}}=$ $5.0 \mathrm{~Hz}$ while the $\mathrm{H}-3^{\prime}$ appeared as doublet of doublet at $\delta=8.29$ ppm with coupling constant $\mathrm{J}_{\mathrm{H} 3^{\prime}, \mathrm{H}^{\prime}}=4.0 \mathrm{~Hz}$.
The hydrogen proton of the hydroxyl group resonates as singlet at $\delta=12.88 \mathrm{ppm} .{ }^{13} \mathrm{C}-\mathrm{NMR}(100 \mathrm{MHz}$, DMSO- $d_{6}$ ) showed a signal at $\delta=103.6 \mathrm{ppm}$ assigned for the $\mathrm{C}-5$ of pyrimidine ring. The $\mathrm{C}-4$ of pyrimidine resonates at $\delta=163.5 \mathrm{ppm}$ and C- 6 appeared at $\delta=$ $160.7 \mathrm{ppm}$, while the signal appeared at $\delta=165.1$ assigned to $\mathrm{C}-2$ of pyrimidine ring. The $\mathrm{CF}_{3}$ group split as quadratic at $120.6 \mathrm{ppm}$. Thiophene carbons resonate at $\delta=129.1,131.1,132.8$ and $140.5 \mathrm{ppm}$.

The synthetic pathway of the new $p$-fluorobenzoyl pyrimidine analogues $4 \mathrm{a}, \mathrm{b}$ is shown in Scheme 1. $p$-Fluorobenzoyl chloride allowed to react with 2-hydroxypyrimidine analogues $3 \mathrm{a}, \mathrm{b}$ in present of a catalytic amount of pyridine under microwave protocol to give the final products $4 \mathrm{a}, \mathrm{b}$ in $85 \%$ and $83 \%$ yields, respectively. The structure of 4-(thien-2'-yl)-6-trifluoromethyl pyrimidin-2-yl 4"-fluorobenzoate 4a was confirmed using IR spectroscopic analysis. The IR spectrum of compound 4a showed a new absorption bands at $1,757 \mathrm{~cm}^{-1}$ due to the carbonyl of the newly formed ester group. The band at $1,603 \mathrm{~cm}^{-1}$ accounted for $\mathrm{C}=\mathrm{C}$ stretch in the aromatic system. While the ether linkage (C-O-C) appeared as two sharp signals at $1,056 \mathrm{~cm}^{-1}$ and $1,246 \mathrm{~cm}^{-1}$. In addition, the ${ }^{1} \mathrm{H}$ NMR spectrum revealed the appearance of new two doublets of doublets at $\delta=7.64$ and $7.92 \mathrm{ppm}$ with coupling constant $\mathrm{J}=4.9$ and $3.7 \mathrm{~Hz}$ respectively assigned to the thiophene protons $\left(\mathrm{H}-3^{\prime}\right.$ \& $\left.\mathrm{H}-5^{\prime}\right)$. The ${ }^{13} \mathrm{C}-\mathrm{NMR}$ spectrum proved the proposed structure due to the appearance of a signal at $\delta=165.4$ ppm corresponding to the carbonyl carbon of the newly formed ester group at pyrimidine $\mathrm{C}-2$, as well as the

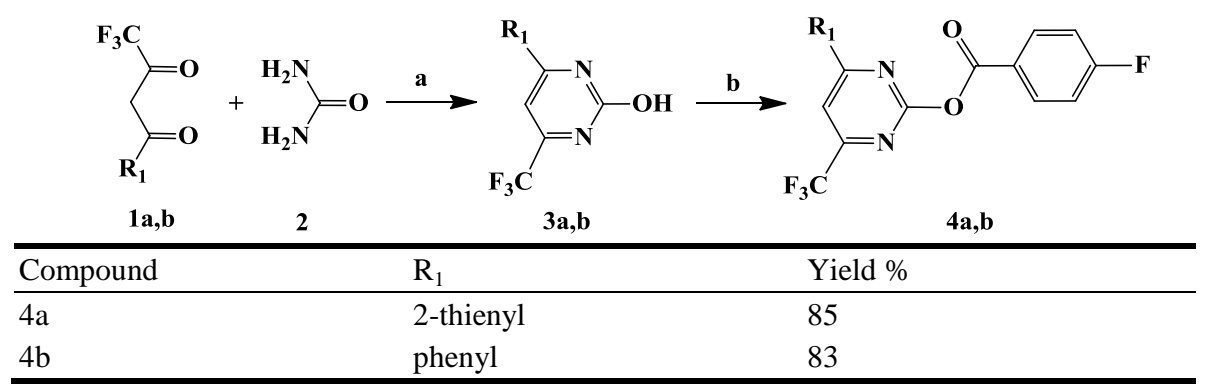

Scheme 1. Microwave synthetic pathways of compounds $4 \mathbf{a}, \mathbf{b}$.

Reagents and conditions: (a) i- MW; $135^{\circ} \mathrm{C}$, ethanol-HCl, ii- $\mathrm{MW} ; 135^{\circ} \mathrm{C}$, acetic acid; (b) $p$-fluorobenzoylchloride, pyridine, $\mathrm{MW}$; $100^{\circ} \mathrm{C}$. 
change in the chemical shift of pyrimidine C-5 to resonate at $\delta=111.9 \mathrm{ppm}$. Moreover, the elemental analysis of compound $4 \mathrm{a}$ with chemical formula $\mathrm{C}_{16} \mathrm{H}_{8} \mathrm{~F}_{4} \mathrm{~N}_{2} \mathrm{O}_{2} \mathrm{~S}$ showed the Anal. Calcd. C, 52.18; H, $2.19 ; \mathrm{N}, 7.61 ; \mathrm{S}, 8.71$. found: C, 52.63; H, 2.26; N, 7.89; S, 8.99.

A $35 \mathrm{~mL}$ CEM Microwave reactor containing 6-trifluoromethyl pyrimidin-2-ol $3 \mathrm{a}, \mathrm{b}$ and 2 equivalents of phosphorus oxychloride $\left(\mathrm{POCl}_{3}\right)$ in ethanol with a catalytic amount of pyridine during 25 min furnished the 2-chloro-6-trifluoromethyl pyrimidine $5 \mathrm{a}, \mathrm{b}$ in $~ 95 \%$ yields (Scheme 2 ). Under conventional conditions, this substitution reaction is typically carried out using $\mathrm{POCl}_{3}$ as a solvent $\left(100^{\circ} \mathrm{C}\right.$, 3-5 h) yielded $5 \mathrm{a}, \mathrm{b}$ in $65-71 \%$ respectively. The structure of the obtained products $5 \mathrm{a}, \mathrm{b}$ was confirmed using ${ }^{1} \mathrm{H}$, and ${ }^{13} \mathrm{C}-\mathrm{NMR}$. The formation of 2-chloro-4-(thien-2'-yl)-6-trifluoromethyl pyrimidine 5 a was confirmed by shifting the signal corresponding to the pyrimidine $\mathrm{H}-5$ from $\delta=7.29 \mathrm{ppm}$ to $\delta=7.84$ ppm. Also, the ${ }^{13} \mathrm{C}$-NMR showed the same shift of the pyrimidine $\mathrm{C}-5$ shifted from $\delta=103.6 \mathrm{ppm}$ to a low field at $\delta=105.2 \mathrm{ppm}$.

Amination of 2-chloro-6-trifluoromethyl pyrimidine $5 \mathrm{a}, \mathrm{b}$ was performed in CEM Microwave using commercially available amines (2 equiv.) in toluene $(15 \mathrm{~mL})$ at $100{ }^{\circ} \mathrm{C}$ and $150 \mathrm{~W}$ for $10 \mathrm{~min}$. The reaction produced the desired 2-( $N$-cycloalkylamino)6-trifluoromethyl pyrimidine 6a-f in 77-89\% isolated yields (Scheme 2).

The formation of 2-( $N$-cycloheptylamino)-4-(thien2'-yl)-6-trifluoromethyl pyrimidine $6 \mathrm{~b}$ was confirmed by elemental analysis, IR, ${ }^{1} \mathrm{H}$ NMR, and ${ }^{13} \mathrm{C}-\mathrm{NMR}$. The IR spectrum of compound $6 \mathrm{~b}$ showed absorption bands at $3,531,3,054,2,884 \mathrm{~cm}^{-1}$ corresponding to the stretching vibration of $\mathrm{NH}, \mathrm{C}-\mathrm{H}$ aromatic and $\mathrm{C}-\mathrm{H}$ aliphatic respectively. The ${ }^{1} \mathrm{H}-\mathrm{NMR}$ spectrum of compound $6 \mathrm{~b}$ showed three multiplets resonated at $\delta=$ 1.55-1.64 ppm, 2.05-2.06 ppm and 4.09 ppm corresponding to 13 protons of cycloheptyl ring. A doublet observed at $\delta=5.36 \mathrm{ppm}$ with coupling constant $\mathrm{J}=4.0 \mathrm{~Hz}$ was attributed to the $-\mathrm{NH}$ proton. While, a singlet corresponding to pyrimidine $\mathrm{H}-5$ shifted to $\delta=7.07 \mathrm{ppm}$. The $2^{\prime}$-thienyl protons $\left(\mathrm{H}-4^{\prime}\right.$, $\mathrm{H}-5^{\prime}$ and $\mathrm{H}-3^{\prime}$ ) resonated at $\delta=7.13,7.50$ and $7.73 \mathrm{ppm}$ respectively. ${ }^{13} \mathrm{C}-\mathrm{NMR}\left(100 \mathrm{MHz}, \mathrm{DMSO}-d_{6}\right)$ showed that the cycloheptyl carbons resonated as four signals at $\delta=24.2,30.9,34.6,53.2 \mathrm{ppm}$. The pyrimidine C-5 shifted to $\delta=101.0 \mathrm{ppm}$, and signals assigned for $\mathrm{C}-2$, C- 4 and C- 6 of the pyrimidine ring resonated at 167.2, 161.7 and 156.9 respectively. Thiophene C-3' ${ }^{\prime}, \mathrm{C}^{-} 4^{\prime}$ and C-5'signals appeared at $\delta=127.1,128.8$ and $131.2 \mathrm{ppm}$ respectively while, the thiophene $\mathrm{C}-2$ ' resonated at $\delta=$ 141.9 ppm.

\subsection{Antibacterial Screening}

Among the antimicrobial agents, derivatives containing thiophene like cephalothin, cephalorodine and cefoxitin exhibit high antimicrobial potency [19]. It is also noticed that the antibacterial activities enhance by the present of 2-thienyl ring at position-4 and this might be based on the fact that 2-thiophene has shown an array of biological activities ranging from antibacterial [20-24], antifungal [25,26], antioxidant [27], and anti-inflammatory activity [28].

The antibacterial assay is based on the comparison of growth inhibition of micro-organisms by measured known concentrations of test compounds with that

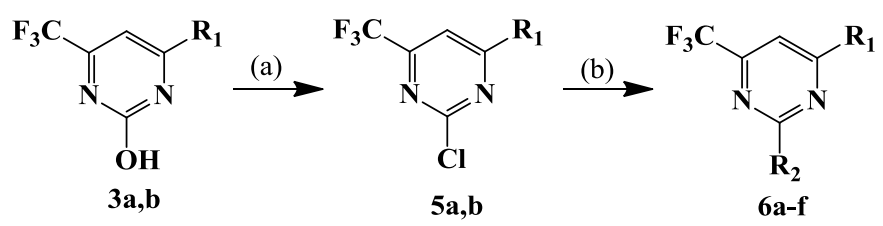

Scheme 2. Synthetic pathway of compounds 5a,b and 6a-f.

Reagents and Conditions: a) i- $\mathrm{MW} ; 100{ }^{\circ} \mathrm{C}, \mathrm{POCl}_{3}, \mathrm{Pyridine}$ or ii- reflux, excess of $\mathrm{POCl}_{3}$; b) 2 equiv. of cyclopentylamine, cycloheptylamine or $N$-Methylpiprazine in toluene, $\mathrm{MW} ; 112{ }^{\circ} \mathrm{C}$. 
produced by known concentrations of standard antibiotics [29]. All of the newly synthesized compounds evaluated against Gram-positive bacteria (Clostridium perfringens, Bacillus pumilus and Enterococcus faecalis), and Gram-negative bacteria (Klebsiella pneumonia). A total of eight compounds were screened for in vitro antibacterial activity. The screening results (Table 2) showed that compounds $4,6 \mathrm{a}, \mathrm{b}$ were found to possess appreciable antibacterial activity with a zone of inhibition greater than $10 \mathrm{~mm}$ against the Gram-positive bacteria compared to the results obtained from three standard drugs, whereas compound $4 \mathrm{~b}$ showed no activity against Bacillus pumilus. Surprisingly, our synthesized analogues with 4-fluorobenzoyloxy $4 \mathrm{a}, \mathrm{b}$ or $N$-cycloalkylamine $6 \mathrm{a}, \mathrm{b}$ substituted at pyrimidine $\mathrm{C}-2$ displayed great antibacterial enhancement against Enterococcus faecalis with an inhibition zones ranging between 11-12 $\mathrm{mm}$ while, the standard drugs used showed zero activity (Fig. 1). When compounds $4 a, b$ tested against Gram-positive bacteria (Bacillus pumilus), 4a showed better activity with inhibition zone of $16 \mathrm{~mm}$ (MIC $12.5 \mu \mathrm{g} / \mathrm{mL}$ ) while, $4 \mathrm{~b}$ gave zero activity when tested against the same bacteria stream. Interestingly, compound $4 \mathrm{~b}$ was found to have two folds more active than $4 \mathrm{a}$ when both derivatives $4 \mathrm{a}$ and $4 \mathrm{~b}$ tested against Gram-positive bacteria (Clostridium perfringens) with inhibition zones of $11 \mathrm{~mm}$ observed from both compounds $4 \mathrm{a}, \mathrm{b}$. The MIC result $(6.25 \mu \mathrm{g} / \mathrm{mL})$ for compound $4 \mathrm{a}$ indicates that an enhancement in the activity observed (MIC $=3.125 \mu \mathrm{g} / \mathrm{mL}$ ) when $4 \mathrm{~b}$ was used. Results obtained from the screening against Gram-negative bacteria (Klebsiella pneumonia) indicate that only compound 4 a showed activity with a zone of inhibition of $11 \mathrm{~mm}$ (MIC $12.5 \mu \mathrm{g} / \mathrm{mL}$ ). The inhibition zones of the newly synthesized compounds are shown in Figs. 2 and 3.

Individual minimum inhibitory concentration (MIC, $\mu \mathrm{g} / \mathrm{mL}$ ) values of active compounds $4 \mathrm{a}, \mathrm{b}$ and $6 \mathrm{a}, \mathrm{b}$ against the test microbes listed in Table 3. The data derived from the MIC test can be correlated with the data obtained from in vitro to estimate the efficacy of the new synthesized derivatives $4 \mathrm{a}, \mathrm{b}$ and $6 \mathrm{a}-\mathrm{f}$.

\section{Conclusion}

In conclusion, novel fluoropyrimidine analogues 3-6a-f have been synthesized using microwave protocols. The antimicrobial screening of the newly synthesized compounds bearing 2-thienyl group substituted at the pyrimidine ring $4 \mathrm{a}, 6 \mathrm{a}, \mathrm{b}$ showed better

Table 1 Yields obtained for compounds 5,6a-f under microwave and conventional methods.

\begin{tabular}{|c|c|c|c|c|c|c|c|}
\hline \multirow{2}{*}{ Compound } & \multirow{2}{*}{$\mathrm{R}_{1}$} & \multicolumn{2}{|c|}{ Yield \% (t) } & \multirow{2}{*}{ Compound } & \multirow{2}{*}{$\mathrm{R}_{1}$} & \multirow{2}{*}{$\mathrm{R}_{2}$} & \multirow{2}{*}{$\frac{\text { Yield } \%}{\text { Microwave }}$} \\
\hline & & Microwave & Conventional & & & & \\
\hline $5 \mathrm{a}$ & 2-thienyl & $96(25 \mathrm{~min})$ & $65(3.5 \mathrm{~h})$ & $6 a$ & 2-thienyl & cylopentylamine & 86 \\
\hline \multirow[t]{5}{*}{$5 b$} & phenyl & $95(25 \mathrm{~min})$ & $71(4 \mathrm{~h})$ & $6 b$ & 2-thienyl & cycloheptylamine & 77 \\
\hline & & & & $6 c$ & 2-thienyl & $N$-methylpiprazine & 89 \\
\hline & & & & $6 \mathrm{~d}$ & phenyl & cylopentylamine & 78 \\
\hline & & & & $6 e$ & phenyl & cycloheptylamine & 83 \\
\hline & & & & $6 f$ & phenyl & $N$-methylpiprazine & 82 \\
\hline
\end{tabular}

Table 2 Inhibition zones (mm) as a criterion of antibacterial activity of the active compounds 4,6a,b.

\begin{tabular}{|c|c|c|c|c|c|c|c|c|}
\hline \multirow{3}{*}{ Bacteria } & & & & & \multicolumn{4}{|c|}{ Inhibition zones (mm) } \\
\hline & \multicolumn{4}{|c|}{ Compounds } & \multirow{2}{*}{-DMSO } & \multirow{2}{*}{ Ampicillin } & \multirow{2}{*}{ Tetracycline } & \multirow{2}{*}{ Streptomycin } \\
\hline & $4 a$ & $4 b$ & $6 a$ & $6 \mathrm{~b}$ & & & & \\
\hline Clostridium perfringens & 11 & 11 & 10 & 13 & 0 & 20 & 31 & 32 \\
\hline Bacillus pumilus & 16 & NA & 11 & 18 & 0 & 33 & 30 & 32 \\
\hline Enterococcus faecalis & 11 & 11 & 11 & 12 & 0 & NA & NA & NA \\
\hline Klebsiella pneumonia & 11 & NA & NA & NA & 0 & 27 & 32 & 30 \\
\hline
\end{tabular}

NA: no activity observed. 


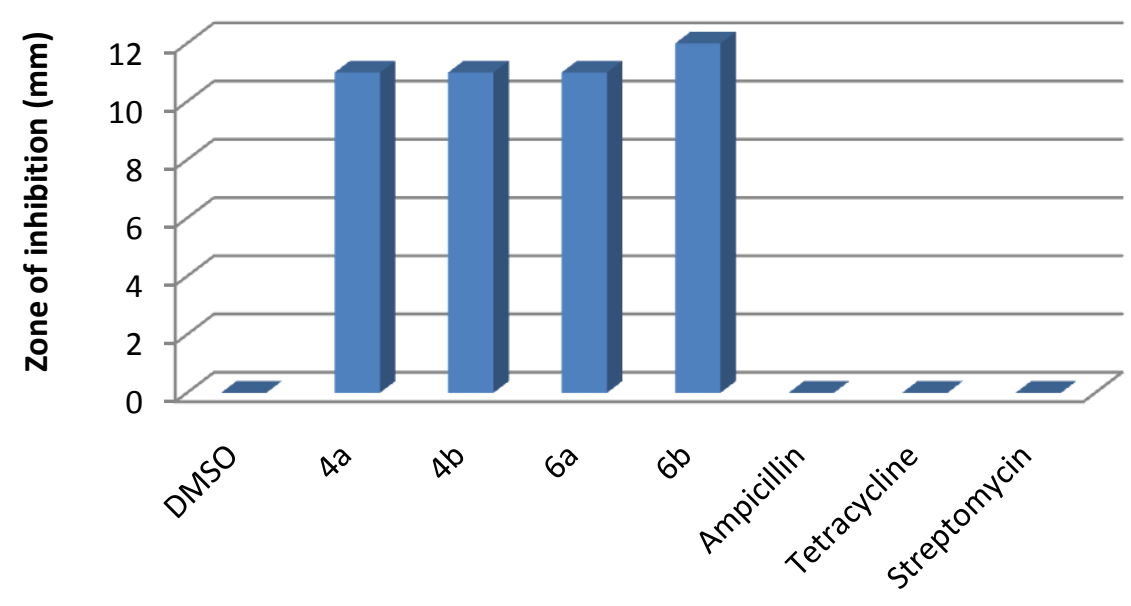

Fig. 1 Comparison of inhibition zones' values of the synthesized compounds 4,6a,b against Enterococcus faecalis vs standards antimicrobial drugs: ampicillin, tetracycline, and streptomycin.

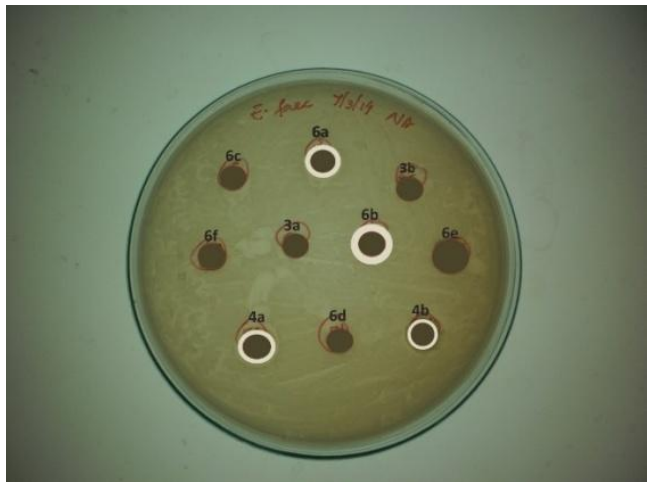

(a)

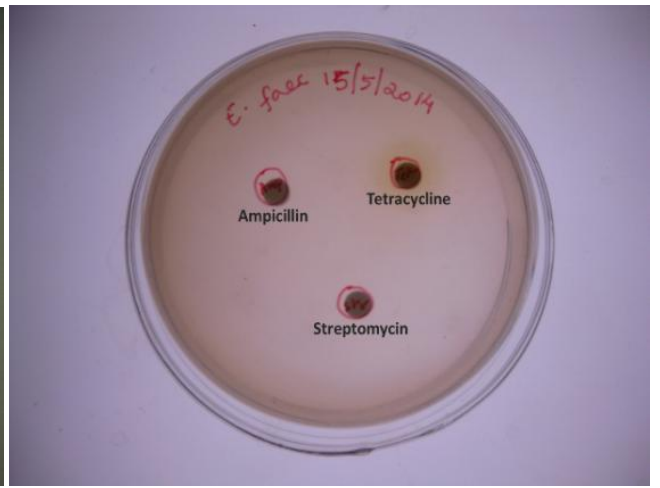

(b)

Fig. 2 (a) zone of inhibition by $4 a, b$, and $6 a, b$ (b) zone of inhibition by standard antimicrobials.

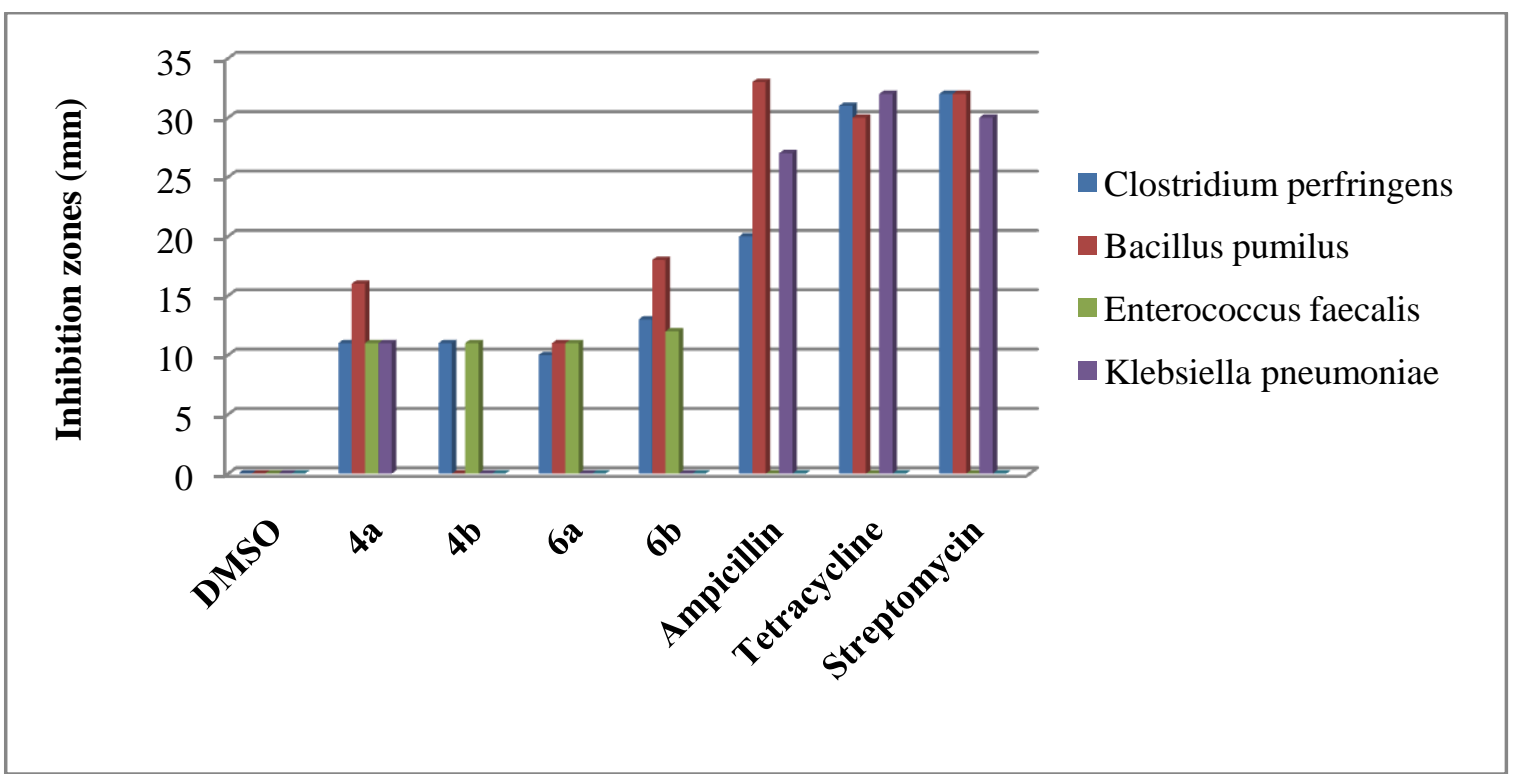

Fig. 3 Inhibition zones (mm) of the newly synthesized compounds 4,6a,b. 
Table 3 Minimal inhibitory concentration (MIC) for compounds 4,6a,b.

\begin{tabular}{lllll}
\hline \multirow{2}{*}{ Compound } & \multicolumn{4}{c}{ MIC $(\mu \mathrm{g} / \mathrm{mL})$} \\
\cline { 2 - 5 } & Enterococcus faecalis & Bacillus pumilus & Clostridium perfringens & Klebsiella pneumoniae \\
\hline $4 \mathrm{a}$ & 50 & 12.5 & 6.25 & 12.5 \\
$4 \mathrm{~b}$ & 50 & - & 3.125 & - \\
$6 \mathrm{a}$ & 25 & 25 & 100 & - \\
$6 \mathrm{~b}$ & 12.5 & 100 & 50 & - \\
\hline
\end{tabular}

antimicrobial activities than other derivatives. For instance, compounds $4,6 \mathrm{a}, \mathrm{b}$ were found to be more effective than the reference drugs, ampicillin, tetracycline and streptomycin, when tested against Gram-positive bacteria (Enterococcus faecalis). Compound $4 \mathrm{a}$ was found to be the only active compound when tested against Gram-negative bacteria (Klebsiella pneumonia). Thus, in the future, this class of compounds can be used as template to design new derivatives that might help to enhance the activity when used to defeat the bacterial infection.

\section{Acknowledgments}

The authors gratefully acknowledge UAE University, Research Affairs Sector for providing financial support (grant no. 31S030-1156-02-02-10).

\section{References}

[1] Zampini, I. C., Cuello, S., Alberto, R. M., Ordonez, R. M., Almeida, R. D., Solorzano, E., and Isla, M. I. 2009. "Antimicrobial Activity of Selected Plant Species from the Argentine Puna against Sensitive and Multi-resistant Bacteria." Journal of Ethnopharmacology 124: 499-505.

[2] Zhi, C., Long, Z-Y., Gambino, J., Xu, W-C., Brown, N. C., Barnes, M., Butler, M., LaMarr, W., and Wright, G. E. 2003. "Synthesis of Substituted 6-Anilinouracils and Their Inhibition of DNA Polymerase IIIC and Gram-Positive Bacterial Growth." Journal of Medicinal Chemistry 46: 2731-9.

[3] Okemo, P. O., Bais, H. P., and Vivanco, J. M. 2003. "In Vitro Activities of Maesa lanceolata Extracts against Fungal Plant Pathogens." Fitoterpia 74: 312-6.

[4] Bounamama, H., Noel, T., Villard, J., Benharref, A., and Jana, M. 2006. "Antimicrobial Activities of the Leaf Extract of Two Moroccan Cistus L Species.” Journal of Ethnopharmacology 104: 104-7.

[5] Hudlicky, M. 1992. Chemistry of Organic Fluorine Compounds. Chichester: Ellis Horwood Ltd..

[6] Filler, A., and Kobayashi, Y. 1981. Biomedical Aspects of
Fluorine Chemistry. Tokyo: Kodansha Ltd.

[7] Welch, J. T. 1987. "Advances in the Preparation of Biologically Active Organofluorine Compounds." Tetrahedron 43: 3123-97.

[8] Guillemont, J., Pasquier, E., Palandjian, P., Vernier, D., Gaurrand, S., Lewi, P. J., Heeres, J., de Jonge, M. R., Koymans, L. M. H., and Daeyaert, F. F. D. 2005. "Synthesis of Novel Diarylpyrimidine Analogues and Their Antiviral Activity against Human Immunodeficiency Virus Type 1." Journal of Medicinal Chemistry 48: 2072-9.

[9] Morgan, J., Haritakul, R., and Keller, P. A. 2008. "Antimalarial Activity of 2,4-Diaminopyrimidines." Letters in Drug Design \& Discovery 5: 277-80.

[10] Cheong, S. L., Dolzhenko, A., Kachler, S., Paoletta, S., Federico, S., Cacciari, B., Dolzhenko, A., Klotz, K-N., Moro, S., and Spalluto, G. 2010. "The Significance of 2-Furyl Ring Substitution with a 2-(Para-Substituted) Aryl Group in a New Series of Pyrazolo-Triazolo- Pyrimidines as Potent and Highly Selective hA3 Adenosine Receptors Antagonists: New Insights into Structure-Affinity Relationship and Receptor-Antagonist Recognition." Journal of Medicinal Chemistry 53: 3361-75.

[11] Dongre, R. S., Bhat, A. R., and Meshram, J. S. 2014. "Anticancer Activity of Assorted Annulated Pyrimidine: A Comprehensive Review." American Journal of PharmTech Research 4: 1-18.

[12] Squarcialupi, L., Colotta, V., Catarzi, D., Varano, F., Betti, M., Varani, K., Vincenzi, F., Borea, P. A., Porta, N., and Ciancetta, A. 2014. "7-Amino-2-phenylpyrazolo [4,3-d]pyrimidine Derivatives: Structural Investigations at the 5-Position to Target Human A1 and A2A Adenosine Receptors. Molecular Modeling and Pharmacological Studies." European Journal of Medicinal Chemistry 84: 614-27.

[13] Sarker, S. D., Nahar, L., and Kumarasamy, Y. 2007. "Microtiter Plate-Based Antibacterial Assay Incorporating Resazurin as an Indicator of Cell Growth, and Its Application in the in Vitro Antibacterial Screening of Phytochemicals." Methods 42: 321-4.

[14] Barry A.L. 1976. The Antimicrobic Susceptibility Test: Principles and Practices. Philadelphia: Lea \& Febiger, 180.

[15] Mueller, K., Faeh, C., and Diederich, F. 2007. "Fluorine in 
Pharmaceuticals: Looking Beyond Intuition." Science 317: 1881-6.

[16] Ismail, F. M. D. 2002. "Important Fluorinated Drugs in Experimental and Clinical Use." Journal of Fluorine Chemistry 118: 27-33.

[17] Bohm, H. J., Banner, D., Bendels, S., Kansy, M., Kuhn, B., Müller, K., Obst-Sander, U., and Stahl, M. 2004. "Fluorine in Medicinal Chemistry." ChemBioChem. 5: 637-643.

[18] Kirk, K. L. 2006. "Fluorine in Medicinal Chemistry: Recent Therapeutic Applications of Fluorinated Small Molecules." Journal of Fluorine Chemistry 127: 1013-29.

[19] Das, B., Srivastava, S., Sarvanan, J., and Mohan, S. 2007. "Synthesis and Antifungal Screening of Some Novel Sulfur Containing Heterocyclic Compounds." Asian J. Chem. 19: 4118-20.

[20] Mohan, S., and Sarvanan, J. 2003. "Synthesis, Characterization and Antibacterial Activity of Some Schiff Bases of 2-Amino-3-(N-Tolyl Carboxamido)-4,5Pentamethylene Thiophenes." Asian J. Chem. 15: 625-7.

[21] Bhaskar, V. H., Kumar, P. P., and Sangameshwaran, B. 2007. "Synthesis, Antimicrobial and Antihyperlipidemic Activities of Some 4-Substituted-5,6,7,8-Tetrahydro [1]Benzo-Thieno[2,3-d]pyrimidines." Asian J. Chem. 19: 5187-94.

[22] Tehranchian, S., Akbarzadeh, T., Reza Fazeli, M., Jamalifar, H., and Shafiee, A. 2005. "Synthesis and Antibacterial Activity of 1-[1,2,4-Triazol-3-yl] and 1-[1,3,4-Thiadiazol-2-yl]-3-Methylthio-6,7-

Dihydrobenzo[c]Thiophen-4(5H)ones." Bioorganic \& Medicinal Chemistry Letters 15: 1023-5.

[23] Ferreira, I. R., Calhelha, R. C., Estevinho, L. M., Queiroz, M-J. R. P. 2004. "Screening of Antimicrobial Activity of
Diarylamines in the 2,3,5-Trimethylbenzo [b]Thiophene Series: A Atructure-Activity Evaluation Study." Bioorganic \& Medicinal Chemistry Letters 14: 5831-3.

[24] Mohan, S., and Saravanan, J. 2003. "Synthesis, Characterization and Antibacterial Activity of Some Schiff Bases of 2-Amino-3-(N-Tolyl Carboxamido)4,5,6,7-Tetrahydro Benzo(b)Thiophenes." Asian J. Chem. 15: 67-70.

[25] Ryu, C-K., Lee, S-K., Han, J-Y., Jung, O-J., Lee, J. Y., and Jeong, S. H. 2005. "Synthesis and Antifungal Activity of 5-Arylamino-4,7-Dioxobenzo[b]Thiophenes." Bioorganic \& Medicinal Chemistry Letters 15: 2617-20.

[26] Plech, T., Paneth, A., Kapron, B., Kosikowska, U., Malm, A., Strzelczyk, A., and Stączek, P. 2014. "StructureActivity Relationship Studies of Microbiologically Active Thiosemicarbazides Derived from Hydroxybenzoic Acid Hydrazides." Chem. Biol. Drug Des. 2014, DOI: 10.1111/cbdd.12392

[27] Torres, R. J., Peters, G. J., and Puig, J. G. 2014. "Novel Developments in Metabolic Disorders of Purine and Pyrimidine Metabolism and Therapeutic Applications of Their Analogs." Nucleosides, Nucleotides \& Nucleic Acids 33: 165-73.

[28] Vishant, P., Tarulata, S., and Akshay, G. 2014. "Synthesis, Characterization and Antimicrobial Activity of Mannich Bases of Ethyl 5-(2-Chlorophenyl)-7Methyl-3-Oxo-3,5-Dihydro-2H-Thiazolo [3,2-a] Pyrimidine-6-Carboxylate Derivatives." Pharmacia Sinica 5: 63-70,

[29] Read, M. L., Brændvang, M., Miranda, P. O., and Gundersen, L-L. 2010. "Synthesis and Biological Evaluation of Pyrimidine Analogs of Antimycobacterial Purines." Bioorganic and Medicinal Chemistry 18: 3885-97. 